\title{
KARAKTERISASI ZAT WARNA DAUN JATI (Tectona grandis) FRAKSI METANOL: $n$-HEKSANA SEBAGAI PHOTOSENSITIZER PADA DYE SENSITIZED SOLAR CELL
}

\author{
Aminuddin Baharuddin*, Aisyah, Jawiana Saokani \& Indah Ayu Risnah \\ Jurusan Kimia UIN Alauddin Makassar \\ *Alamat Korespodensi :aminuddinbaharuddin@yahoo.com
}

\begin{abstract}
Abstrak: Penyedia energi saat ini masih didominasi oleh sumber energi yang tidak dapat diperbaharui seperti batubara, minyak bumi dan gas alam. Semakin lama sumber energi ini akan semakin menipis jumlahnya di alam sehingga dibutuhkan sumber energi terbarukan. Salah satu sumber energi yang potensial dikembangkan di Indonesia adalah DSSC (Dye Sensitized Solar Cell). Dalam penelitian ini digunakan zat warna daun tumbuhan Tectona grandis sebagai photosensitizer. Zat warna diperoleh dari proses ekstraksi menggunakan alat ultrasonik dengan pelarut metanol. Pengujian DSSC dilakukan pada zat warna dalam keadaan asam ( $\mathrm{pH} 6)$ dan keadaan basa $(\mathrm{pH} 11)$ serta pada hasil pemisahan KKCV menggunakan eluen n-hexana-metanol (8:2, 5:5, dan 2:8). Nilai efisiensi paling tinggi diperoleh pada hasil KKCV n-hexana:metanol 5:5 yakni sebesar 0,05127\%. Karakterisasi dilakukan pada zat warna yang miliki efisensi paling tinggi dengan menggunakan UV-Vis, FTIR dan GC-MS. Hasil analisis UV-Vis menunjukkan adanya serapan pada panjang gelombang $522 \mathrm{~nm}$ yang merupakan daerah serapan khas antosianin. Pada pengujian FTIR didapatkan beberapa gugus fungsi yang teridentifikasi sebagai $-\mathrm{OH}, \mathrm{C}-\mathrm{H}$, dan $\mathrm{C}=\mathrm{C}$. Hasil analisis dengan GC-MS menunjukkan fragmen puncak pada m/z 287. Secara umum hasil karakterisasi tersebut besesuaian dengan salah satu pigmen antosianin yaitu sianidin.
\end{abstract}

Kata Kunci: DSSC, efisiensi, photosensitizer, Tectona grandis

Abstract: Energy supplier nowdays is still dominated by the energy source that cannot be renewed, such as coal, oil and natural-gas. Depletion of oil reserve is the only option in the future so the renewable energy source is needed. One of the most potential energy sources that have been developed in Indonesia is DSSC (Dye Sensitized Solar Cell). Research about DSSc using teak leaf dye as the photosensitizer was done. The dye was obtained through extracting process using ultrasonic device with methanol as resolving. DSSC tasted to pigment in acid ( $\mathrm{pH} \mathrm{6)}$ and alkali ( $\mathrm{pH} \mathrm{11)}$ and result of $\mathrm{KKCV}$ isolation using eluent $n$-hexane:methanol (8;2, 5:5 and 2:8). The highest efficiency value was from KKCV n-hexane:methanol 5:5 with 0,05127\%. Characterization was tasted to the pigment with the highest efficiency by using UV-Vis, FTIR and GC-MS. The result from UV-Vis indicated absorption in wave lenght $522 \mathrm{~nm}$ which absorption area specific to anthocyanin. In FTIR tes, was obtained some cluster functions which identified as $-\mathrm{OH}, \mathrm{C}-\mathrm{H}$ and $\mathrm{C}=\mathrm{C}$. Result from using $G \mathrm{C}-\mathrm{MS}$ analysis showed the top fragment was at $m / z=287$. Generally the result of the characterization is appropriate with one of the anthocyanin pigment which is cyanidin.

Keywords: DSSC, efficiency, photosensitizer and Tectona grandis.

\section{PENDAHULUAN}

Sel Surya merupakan suatu perangkat yang dapat mengkonversi energi matahari menjadi energi listrik. Sel surya telah banyak dikembangkan oleh para peneliti mulai dari sel surya berbahan silikon tunggal, silikon polikristal sampai pada sel surya jenis terbaru yakni Dye Sensitized Solar Cell (DSSC). DSSC pertama kali ditemukan pada tahun 1991 oleh O'Regan dan Gratzel yang menggunakan ekstrak zat warna yang terdapat pada tumbuhan sebagai penangkap cahaya matahari dan mengubahnya menjadi energi listrik.

DSSC terdiri dari beberapa komponen penting yakni kaca TCO (Transparant Condukting Oxide), $\mathrm{TiO}_{2}$ (Titanium Oxide), zat warna dan elektrolit (O’Regan \& Gratzel, 1991). Kaca TCO (Transparant Conducting Oxide) mengapit sistem secara keseluruhan. Kaca bagian atas berfungsi sebagai elektroda sedangkan kaca pada bagian bawah berfungsi sebagai elektroda pembanding (counter- elektroda). Kaca TCO yang paling banyak digunakan dalam pembuatan DSSC adalah flourine-doped tin oxide (FTO atau $\mathrm{SnO}_{2}: \mathrm{F}$ ) dan indium tin oxide (ITO atau $\left.\mathrm{In}_{2} \mathrm{O}_{3}: \mathrm{Sn}\right)$.

$\mathrm{TiO}_{2}$ digunakan sebagai semikonduktor dalam pembuatan DSSC. Nanokristal $\mathrm{TiO}_{2}$ memiliki tiga bentuk yang berbeda yakni rutile, anatase, dan brookit (Sastrawan, 2006). Dari ketiga bentuk tersebut yang paling sering digunakan adalah hanya kristal $\mathrm{TiO}_{2}$ anatase (Sastrawan, 2006). Hal ini disebabkan karena $\mathrm{TiO}_{2}$ anatase bersifat fotoaktif dibanding $\mathrm{TiO}_{2}$ rutile dan brookit.

Elektrolit pada DSSC bisa berupa padatan maupun cairan. Elektrolit yang paling sering digunakan dalam pembuatan DSSC adalah pasangan redoks $\mathrm{I}^{-} / \mathrm{I}_{3}^{-}$(iodin/triiodida). Selain pasangan elektron $\mathrm{I}^{-} / \mathrm{I}_{3}{ }^{-}$, elektrolit yang dapat digunakan adalah $\mathrm{Br}_{2} / \mathrm{Br}^{-}, \quad(\mathrm{SCN})_{2} / \mathrm{SCN}^{-}$dan $(\mathrm{SeCN})_{2} / \mathrm{SeCN}^{-}$. Akan tetapi, pasangan redoks alternatif ini masih memiliki korosi yang tinggi dan bersifat toksik sehingga 
sampai saat ini $\mathrm{I}^{-} / \mathrm{I}_{3}^{-}$masih merupakan elektrolit terbaik untuk DSSC (Zhang, 2008).

Komponen yang tidak kalah penting adalah zat warna. Zat warna yang digunakan dapat berupa zat warna sintesis maupun zat warna alami. DSSC dengan zat warna sintesis yang digunakan oleh Mathew dkk. (2014) telah mencapai efisiensi sebesar $13 \%$ sedangkan DSSC dengan zat warna alami yang digunakan oleh Chien dan Hsu (2013) masih redah yakni $1,4 \%$. Walaupun zat warna sintesis memiliki efisiensi yang tinggi tetapi biaya produksi zat warna alami jauh lebih mudah dan juga zat warna alami sangat mudah diperoleh disekitar kita.

Bagian-bagian tumbuhan yang dapat diekstrak untuk dijadikan zat warna alami yakni daun, buah, dan bunga. Telah banyak zat warna alami yang digunakan dalam pembuatan sel surya ini seperti kubis merah (Chien dan Hsu, 2013), buah naga (Nadeak, 2012), kol merah (Maddu, 2007), dan strawberry (Misbachudin dkk., 2013). Zat warna dalam tanaman yang biasanya digunakan dalam DSSC adalah klorofil, karotenoid, antosianin, flavonoid, dan tanin (Ludin, dkk, 2014).

Salah satu zat warna yang dapat dijadikan sel surya organik adalah zat warna dari daun jati. Jati (Tectona grandis) merupakan tanaman kayu berkualitas tinggi. Kayu jati sebagai bahan baku furniture telah banyak digunakan oleh berbagai negara di dunia sehingga banyak di budidayakan. Dengan banyaknya budidaya jati meyebabkan jumlah daun jati menjadi sangat melimpah. Daun jati selama ini masih belum banyak dimanfaatkan dalam kehidupan sehari-hari sehingga hanya akan terbuang secara sia-sia, padahal daun jati memiliki beberapa zat warna seperti antosianin dan karatenoid yang dapat dijadikan sebagai bahan dasar dalam pembuatan DSSC.

\section{BAHAN DAN METODE}

Penelitian ini telah dilakukan pada bulan November 2015 sampai Februari 2016. Preparasi sampel dilakukan di Laboratorium Kimia Organik Universitas Islam Negeri Alauddin Makassar, analisis UV-Vis dan FTIR dilakukan di Laboratorium Kimia Terpadu Universitas Hasanuddin Makassar, analisis GC-MS dilakukan di Laboratorium Kimia Balai Besar Laboratorium Kesehatan Makassar dan uji Scanning Electron Microscopy (SEM) dilakukan di Laboratorium Mikrostruktur Universitas Negeri Makassar.

\section{Bahan}

Bahan-bahan yang digunakan dalam penelitian ini yaitu, aquades $\left(\mathrm{H}_{2} \mathrm{O}\right)$, daun jati (Tectona grandis) metanol $\left(\mathrm{CH}_{3} \mathrm{OH}\right)$ teknis, iodida $\left(\mathrm{I}_{2}\right)$ teknis, kalium iodida (KI) teknis, $n$-heksan $\left(\mathrm{C}_{6} \mathrm{H}_{14}\right)$ teknis, titanium oksida $\left(\mathrm{TiO}_{2}\right)$ teknis, kertas saring, lilin, natrium hidroksida $(\mathrm{NaOH}) \quad 10 \%$ dan silika $\mathrm{G}_{60}$ nomor katalog 7730 dan 7733.
Metode

1. Ektraksi dan Karakterisasi Zat Warna pada Daun Jati

\section{a. Ekstraksi Daun Jati}

Sampel daun jati yang diambil adalah daun jati yang masih muda. Kemudian dikeringkan pada suhu kamar. Setelah itu, sampel dihaluskan dengan menggunakan blender. Kemudian diekstraksi menggunakan alat utrasonik dengan pelarut metanol selama 15 menit. Ekstrak kemudian disaring dengan kertas saring lalu dipekatkan dengan menggunakan rotary evaporator.

\section{b. Variasi pH}

Ekstrak yang didapatkan diencerkan dengan metanol kemudian ditambahkan dengan $\mathrm{NaOH}$ $10 \%$ hingga berubah dari pH 6 (warna merah) ke pH 11 (warna ungu).

\section{c. $\mathrm{KKCV}$}

Silika 7730 ditimbang \pm 20 gram lalu dimasukkan ke dalam kolom KKCV, lalu dialiri dengan $\mathrm{n}$-heksan hingga tidak terdapat gelembung udara pada silika 7730. Setelah itu, ekstrak kental daun jati diencerkan lalu diimpregnasi dengan silika 7733 sebanyak \pm 3 gram. Hasil impregnasi sampel lalu dimasukkan ke dalam kolom KKCV yang selanjutnya dialiri dengan eluen yang ditingkatkan kepolarannya. Eluen yang digunakan yaitu perbandingan antara n:heksan dan metanol (8:2; 5:5 dan 2:8).

\section{Pembuatan Dan Pengujian DSSC}

\section{a. Pembuatan Pasta $\mathrm{TiO}_{2}$}

$\mathrm{TiO}_{2}$ dilarutkan dengan aquades panas kemudian diendapkan lalu disaring. Endapan $\mathrm{TiO}_{2}$ kemudian dilarutkan dengan etanol hingga berbentuk pasta.

\section{b. Preparasi Larutan Elekrtolit}

Kalium iodida ditimbang 0,83 gram lalu ditambahkan iod sebanyak 0,127 gram. Kemudian dilarutkan dalam $10 \mathrm{~mL}$ aquades

\section{c. Pembuatan elektroda pembanding}

Kaca TCO terlebih dahulu dibersihkan dengan aquades dalam ultrasonik lalu dikeringkan. Setelah itu, kaca TCO dipanaskan diatas api hingga terbentuk lapisan warna hitam.

\section{d. Rangkaian Dan Pengujian Sel Surya Organik}

Kaca TCO diberi selotip kemudian dilapiskan dengan pasta $\mathrm{TiO}_{2}$. Setelah itu dilakukan pemanasan pada kaca selama 30 menit dan biarkan sampai kaca TCO dingin. Kaca kemudian ditetesi dengan zat warna dan didiamkan sampai zat warna meresap ke dalam $\mathrm{TiO}_{2}$. Setelah meresap, ditambahkan dua tetes larutan elektrolit dan ditempelkan pada elektroda pembanding secara berhadapan. Perangkat sel surya kemudian diuji dengan menggunakan multimeter di bawah sinar matahari. Arus dan tegangan yang didapat dicatat. 


\section{Karakterisasi}

Karakterisasi zat warna dilakukan dengan mengambil zat warna yang memiliki efisiensi yang paling tinggi dan dianalisis dengan menggunakan Spektrofotometer UV-Vis, Spektroskopi FTIR dan GC-MS sedangkan karakteristik morfologi $\mathrm{TiO}_{2}$ dilakukan dengan menggunakan SEM.

\section{HASIL DAN PEMBAHASAN}

Hasil pengujian DSSC pada pH 6 dan dan $\mathrm{pH} 11$ serta hasil KKCV dapat dilihat pada Tabel 1 dan 2.

Tabel 1. Pengukuran DSSC pada Ekstrak pH 6 dan $\mathrm{pH} 11$

\begin{tabular}{cccccc}
\hline $\begin{array}{c}\text { Variasi } \\
\mathrm{pH}\end{array}$ & $\begin{array}{c}I_{\max } \\
(\mu \mathrm{A})\end{array}$ & $\begin{array}{c}V_{\max } \\
(\mathrm{mV})\end{array}$ & $\begin{array}{c}P_{\text {in }} \\
\left(\mathrm{mW} / \mathrm{cm}^{2}\right)\end{array}$ & $\begin{array}{c}P_{\max } \\
(\mathrm{mW})\end{array}$ & $\begin{array}{c}\eta \\
(\%)\end{array}$ \\
\hline $\mathrm{pH} \mathrm{6}$ & 12,4 & 178 & 7,61384 & 0,0022072 & 0,02898 \\
$\mathrm{pH} \mathrm{11}$ & 20,1 & 56 & 9,473374 & 0,0011256 & 0,01188
\end{tabular}

Ket: $I_{\max }$ (arus maksimum), $\mathrm{V}_{\max }$ (Tegangan maksimum), $P_{\text {in }}$ (Daya yang diterima), $P_{\max }$ (Daya maskimum), $\eta$ (Efisiensi)

Tabel 2. Pengukuran DSSC Hasil KKCV menggunakan pelarut $n$-Heksana:Metanol

\begin{tabular}{cccccc}
\hline $\mathrm{KKCV}$ & $\begin{array}{c}I_{\max } \\
(\mu \mathrm{A})\end{array}$ & $\begin{array}{c}V_{\max } \\
(\mathrm{mV})\end{array}$ & $\begin{array}{c}P_{i n} \\
\left(\mathrm{~mW} / \mathrm{cm}^{2}\right)\end{array}$ & $\begin{array}{c}P_{\max } \\
(\mathrm{mW})\end{array}$ & $\begin{array}{c}\eta \\
(\%)\end{array}$ \\
\hline $8: 2$ & 24 & 49 & 9,531942 & 0,001176 & 0,01234 \\
$5: 5$ & 61 & 64 & 7,61384 & 0,003904 & 0,05127 \\
$2: 8$ & 12,9 & 40 & 9,531942 & 0,000516 & 0,00541 \\
\hline
\end{tabular}

Ket: $I_{\max }$ (arus maksimum), $\mathrm{V}_{\max }$ (Tegangan maksimum), $P_{\text {in }}$ (Daya yang diterima), $P_{\max }$ (Daya maskimum), $\eta$ (Efisiensi)

\section{Efisiensi DSSC pada Keadaan Asam dan Basa}

Pengujian DSSC yang dilakukan pada keadaan asam $(\mathrm{pH}$ 6) memiliki efisiensi yang lebih besar yakni $0,02898 \%$ dibanding pada keadaan basa $(\mathrm{pH}$ 11). Hal ini disebabkan pada $\mathrm{pH} 6$ zat warna telah terdeprotonasi (kehilangan $\mathrm{H}^{+}$) dari bentuk kation flavilium. Menurut Cherepy dkk. (1997) bahwa dalam bentuk quinonoidal, antosianin akan terikat dengan kuat pada $\mathrm{TiO}_{2}$ dibanding dalam bentuk flavilium (pH 1-2) dapat dilihat pada Gambar 1. Pada $\mathrm{pH}$ yang sangat rendah elektron lebih sulit untuk terdeprotonasi sehingga antosianin menjadi sangat stabil dan sulit berikatan dengan molekul lain. Hal ini menyebabkan ikatan antosianin dengan $\mathrm{TiO}_{2}$ menjadi lemah. Selain itu, muatan yang ada pada kation flavilum dapat menghambat terjadinya perpindahan elektron pada permukaan $\mathrm{TiO}_{2}$ (Chien \& Shu, 2013: 205). Pada $\mathrm{pH} 11$, kandungan antosianin yang dimiliki oleh daun jati semakin menurun (Fatinatullabibah dkk., 2014) sehingga antosianin yang terserap didalam $\mathrm{TiO}_{2}$ juga berkurang. Hal ini menyebabkan berkurangnya efisiensi dibanding pada pH 6. Hal ini sesuai dengan hasil pengujian DSSC yang dilakukan oleh Chien \& Shu (2013) bahwa efisiensi tertinggi dihasilkan pada $\mathrm{pH}$ 6-8. Terjadi penurunan pada keadaan yang lebih asam $(\mathrm{pH} 2$ dan $\mathrm{pH}$ 4) maupun lebih basa (pH 10 dan $\mathrm{pH} 12)$.

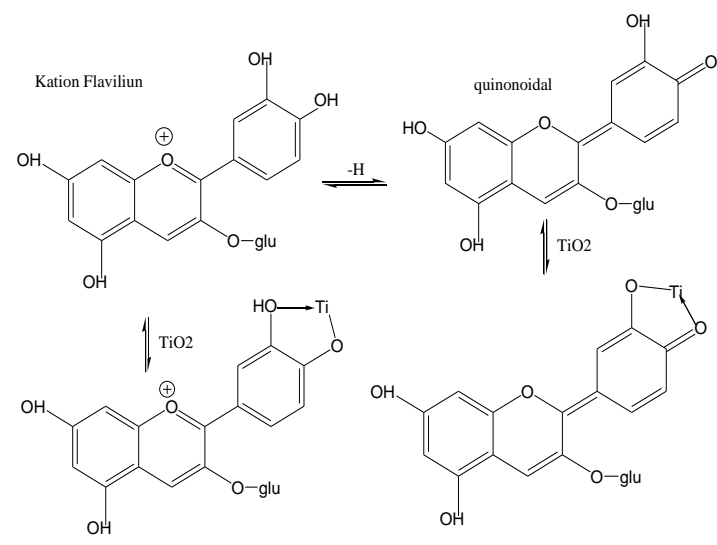

Gambar 1. Pengikatan $\mathrm{TiO}_{2}$ pada antosianin

\section{Efisiensi Hasil KKCV Ekstrak Daun Jati}

Hasil efisiensi DSSC ketiga fraksi adalah $0,01234 \%$ untuk fraksi 8:2, untuk fraksi 5:5 diperoleh efisiensi sebesar 0,05127 \% dan fraksi 2:8 diperoleh efisiensi sebesar 0,00541\%. Efisiensi paling besar dihasilkan oleh fraksi 5:5 dan paling kecil adalah efisiensi dari fraksi 8:2. Efisiensi yang didapatkan ini masih tergolong rendah dibandingkan dengan hasil Chien \& Hsu (2013) yang menggunakan kubis merah sebagai sensitizer dan berhasil mendapatkan efisiensi sebesar $1,4 \%$. Besarnya efisiensi pada fraksi 5:5 bisa jadi disebabkan karena zat warna yang dimiliki oleh fraksi 5:5 lebih banyak yang teradsorpsi pada $\mathrm{TiO}_{2}$ dibanding kedua fraksi lainnya. Semakin banyak zat warna yang teradsorpsi pada $\mathrm{TiO}_{2}$ menyebabkan semakin banyak foton (cahaya) yang terserap sehingga daya yang dihasilkan akan semakin besar pula. Perbedaan adsorbsi ketiga fraksi kemungkinan besar disebabkan oleh jenis senyawa dari ketiga sampel yang berbeda-beda. Sehingga untuk mengetahui senyawa dari zat warna yang memiliki efisiensi paling besar maka dilakukanlah karakterisari.

\section{Morfologi $\mathrm{TiO}_{2}$}

Karakteristik morfologi dari $\mathrm{TiO}_{2}$ yang terikat zat warna dapat dilihat pada Gambar 2. Pada hasil SEM terlihat bahwa penyebaran zat warna pada permukaan $\mathrm{TiO}_{2}$ yang kurang merata. Terdapat zat warna yang teradsorpsi dengan baik dan ada pula zat warna yang tidak teradsorpsi dan membentuk gumpalan-gumpalan. Adanya gugus hidroksil (-OH) dan karbonil $(\mathrm{C}=\mathrm{O})$ pada suatu zat warna memungkinkan terbentuknya ikatan yang kuat dengan permukaan $\mathrm{TiO}_{2}$. Selain itu hasil SEM juga menunjukkan bahwa ukuran partikel dari $\mathrm{TiO}_{2}$ tergolong besar (mikrometer) sehingga hanya dapat menampung sedikit zat warna. Hal inilah yang menyebabkan zat warna yang teradsorpsi dalam $\mathrm{TiO}_{2}$ sedikit sehingga efisiensi yang dihasilkan juga tidak maksimal. 
(a)

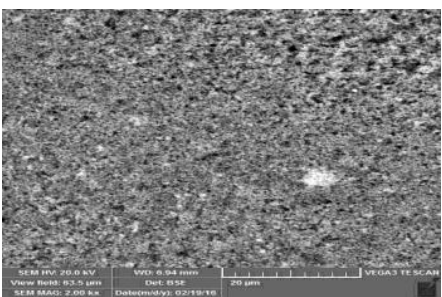

(b)

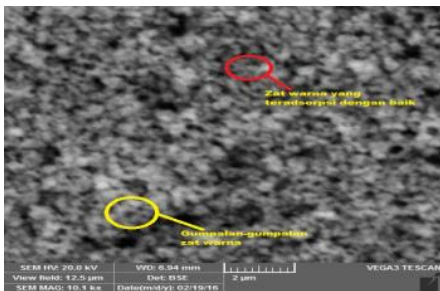

Gambar 2. Hasil SEM permukaan $\mathrm{TiO}_{2}$ yang mengikat zat warna. (a) $20 \mu \mathrm{m}$ dan (b) $2 \mu \mathrm{m}$.

\section{Karakterisasi Zat Warna}

Karakterisasi dilakukan pada fraksi yang memiliki efisiensi paling besar. Tujuan karakterisasi ini untuk mengetahui jenis senyawa yang terdapaat dalam sampel tersebut. Adapun parameter yang digunakan dalam karakterisasi adalah UV-Vis, FTIR dan GC-MS.

Pengujian ekstrak daun jati hasil KKCV pada UV-Vis dimaksudkan untuk mengetahui panjang gelombang pada fraksi yang memiliki efisiensi paling tinggi. Hasil UV-Vis dapat dilihat pada Gambar 3.

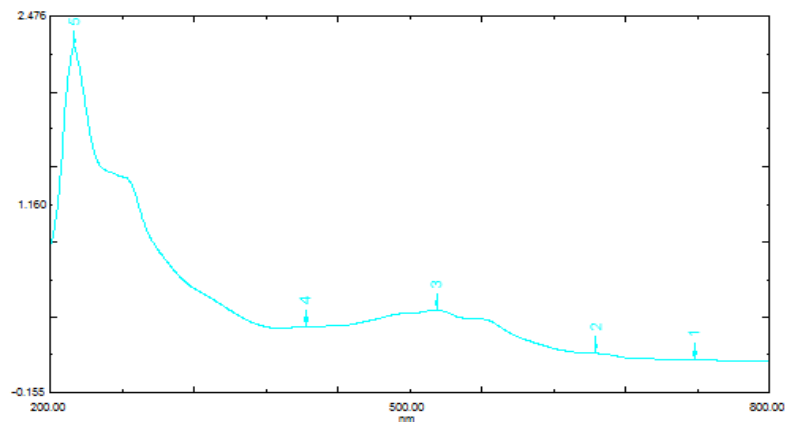

Gambar 3. Hasil Karakterisasi dengan UV-Vis

Berdasarkan hasil UV-Vis, terdapat serapan pada daerah UV (200- $400 \mathrm{~nm}$ ) dan pada daerah tampak (400-800 nm). Penyerapan yang terjadi pada daerah UV dengan panjang gelombang $220 \mathrm{~nm}$ merupakan panjang gelombang dari pelarut yang digunakan. Pada daerah tampak, penyerapan paling tinggi terjadi pada panjang gelombang $522 \mathrm{~nm}$ dengan absorbansi sebesar 0,452. Daerah ini merupakan daerah panjang gelombang khas yang dimiliki oleh antosianin (475$550 \mathrm{~nm}$ ) (Harborne, 1987).

FTIR merupakan salah satu instrumen penting dalam mengidentifikasi gugus-gugus fungsi dalam suatu senyawa. Spektrum FTIR menunjukkan vibrasi ikatan-ikatan yang terdapat dalam senyawa. Analisis FTIR dilakukan pada bilangan gelombang 4500-500 $\mathrm{cm}^{-1}$.

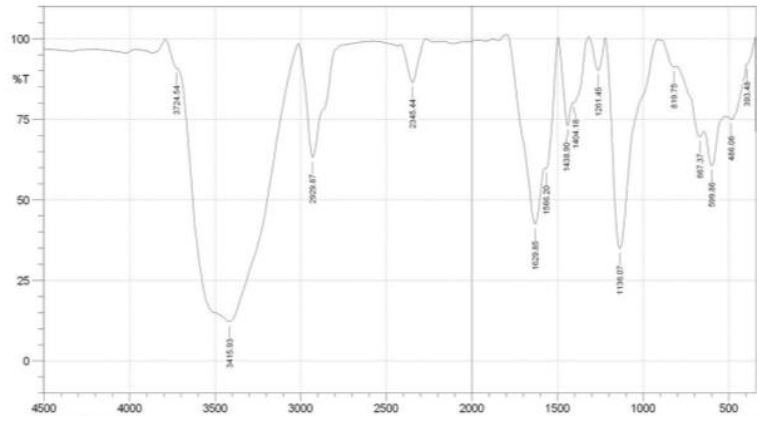

Gambar 4. Hasil Karakrerisasi zat warna dengan FTIR

Hasil FTIR pada Gambar 4 menujukkan adanya serapan pada bilangan gelombang yang berbedabeda. Terdapat serapan yang lebar dengan intensitas yang kuat yang menunjukkan adanya gugus $\mathrm{OH}$ pada bilangan gelombang $3425 \mathrm{~cm}^{-1}$. Hasil spektrum juga menunjukkan adanya serapan yang tajam dengan intensitas sedang pada bilangan gelombang $2929 \mathrm{~cm}^{-1}$ yang diduga merupakan ikatan $\mathrm{C}-\mathrm{H}$. Pada bilangan gelombang $1629 \mathrm{~cm}^{-1}$ terdapat serapan yang tajam yang diduga merupakan serapan ikatan rangkap $\mathrm{C}=\mathrm{C}$. Secara keseluruhan, gugus-gugus fungsi tersebut bersesuaian dengan gugus fungsi yang terdapat pada kerangka dasar antosianin.

Analisis GC-MS memungkinkan untuk mengetahui berat molekul dari senyawa yang berada dalam sampel. Hasil analisis yang dilakukan terhadap hasil KKCV zat warna daun jati menghasilkan spektrum massa dengan waktu retensi 12,35 dan puncak utama pada $m / z 287$ (Gambar IV.8). Berat molekul ini mirip dengan salah satu berat molekul senyawa antosianin yaitu sianidin. Menurut Ferrars (2014) bahwa fragmen dasar dari sianidin adalah 287, 241, 213, dan 137. Fragmen $m / z 241$ dihasilkan oleh lepasnya gugus karbonil $(\mathrm{C}=\mathrm{O})$ dan $\mathrm{H}_{2} \mathrm{O}$ dari gugus utama $(\mathrm{m} / \mathrm{z}$ 287). Molekul sisa $(\mathrm{m} / \mathrm{z} 241)$ selanjutnya pecah kembali dengan melepaskan gugus karbonil $(\mathrm{C}=\mathrm{O})$ menghasilkan fragmen dengan puncak $\mathrm{m} / \mathrm{z}$ 213. Data beberapa fragmen dapat dilihat pada Gambar 5.

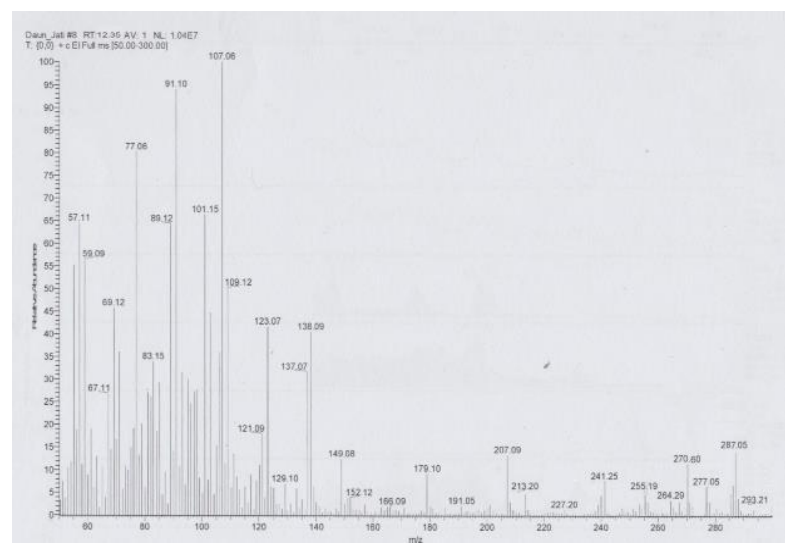

Gambar 5. Hasil Karakterisasi Zat Warna dengan GC-MS 


\section{KESIMPULAN}

Efisiensi DSSC yang dihasilkan dalam keadaan asam (pH 6) dan keadaan basa ( $\mathrm{pH} 11)$ yakni 0,02898 $\%$ dan $0,01188 \%$. Efisiensi yang dihasilkan pada KKCV menggunakan pelarut n-heksana : metanol adalah 0,01234\% untuk fraksi 8:2, untuk fraksi 5:5 diperoleh efisiensi sebesar 0,05127 \% dan fraksi 2:8 diperoleh efisiensi sebesar $0,00541 \%$. Karakterisasi zat warna menggunakan UV-Vis, GC-MS, dan FTIR secara keseluruhan menunjukkan bahwa salah satu zat warna golongan antosianin yang terdapat dalam ekstrak daun jari adalah sianidin.

\section{DAFTAR PUSTAKA}

Cherepy, N.J., Smestad, M., Graetzel, M., \& Zhang, J.Z. (1997). Ultrafast electron injection: implications for a photoelectrochemical cell utilizing an anthocyanin dye-sensitized2 nanocrystalline electrode, Journal of Physical Chemistry, 101, 9342-9351.

Chien, C. \& Hsu, B. (2013). Optimization of the dyesensitized solar cell with anthocyanin as photosensitizer, Solar Energy, 203-211

Fatinatullabibah, K. \& Khasanah, L.U. (2014). Stabilitas antosianin ekstrak daun jati (Tectona grandis) terhadap perlakuan $\mathrm{pH}$ dan suhu, Jurnal Aplikasi Teknologi Pangan, 2, 60-63.

Ferrars, R.M., Czank, C., Zhang, Q., Botting, N.P., Kroon, P.A. \& Cassidy, A. (2014). The pharmacokinetics of anthocyanins and their metabolites in humans, Journal of Pharmacology, 171(13), 3268-3282.

Harbone, J.B. (1987). Metode fitokimia: penuntun cara modern menganalisis tumbuhan (Phytochemical methods, terjemahan Kosasih Padmawinata dan Iwang Soediro), ITB, Bandung.

Ludin, N.A., Mahmoud, A.M.A., Muhammad, A.B., Kadhum, A.A.H., Sopian, K., \& Karim, N.S.A.
(2014). Review on development of natural dye phoyosentisizer for dye-sensitized solar cells, Renewable and Sustinable Energy Review, 31, 386-396.

Maddu, A., Zuhri, M., \& Irmansyah. (2007). Penggunaan ekstrak antosianin kol merah sebagai photosensitizer pada sel surya TiO, nanokristal tersensitisasi dye, Makara Teknologi, 11(2), 78-84.

Mathew, S., Yella, A., Gao, P., Humpry-Baker, R., Curchod, B.F.E., Ashari-Astani, N., Tavernelly, I., Rothlisberger, U., Nazeerudin, M.K., \& Gratzel, M., (2014). Dye-sensitized solar cells with $13 \%$ efficiency achieved through the molecular engineering of porphyrin sensitizers, Nature Chemistry, 6, 242-247

Misbachuddin, M.C., Trihandaru, S. \& Sutresno, A. (2013). Studi awal ekstrak antosianin strawberry sebagai sensitizer solar cell (DSSC), Proceeding of $2^{\text {nd }}$ Lontar Physics Forum, pp. 15.

Nadeak, S.M. \& Susanti, D. (2012). Variasi temperatur dan waktu tahan kalsinasi terhadap unjuk kerja semikonduktor $\mathrm{TiO}$, sebagai dye sensitized solar cell (DSSC) dengan dyes ekstrak buah naga merah, Jurnal Teknik ITS, 1, 81-86.

Sastrawan, R. (2006). Photovoltaic modules of dye solar cell. Ph.D. Thesis, Fakultat Fur Mathematik und Physik Universitat Freiburg, Breisgau.

O’Regan, B. \& Gratzel. (1991). A low-cost, highefficiency solar cell based on dye-sensitized collonidal $\mathrm{TiO}_{2}$ film, Nature, 353, 737-740.

Zhang, Z. (2008). Enhancing the open-circuit voltage of dye-sensitized solar cells: coadsorbents and alternative redox couples, Thesis, Faculte Science De Base, Suissa. 